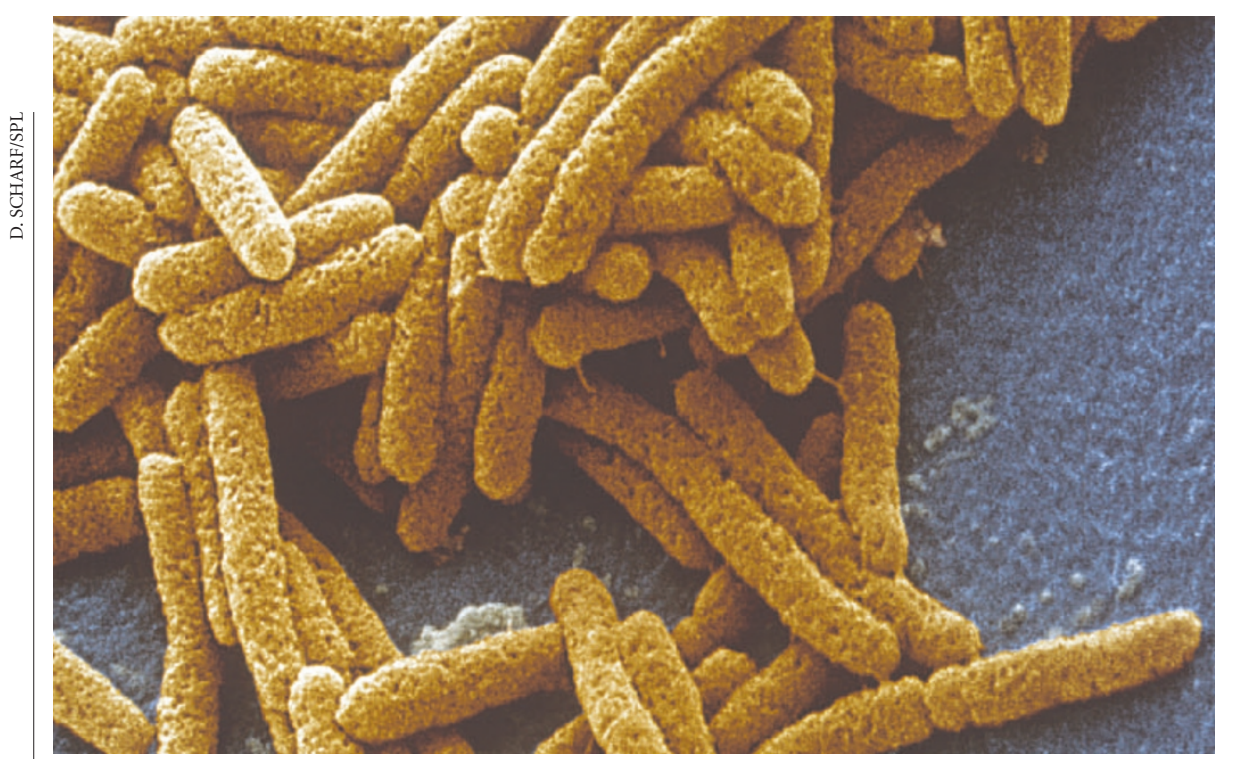

Write stuff: is work on Escherichia coli being ignored in the scramble to fund bioterror research?

\title{
Protest letter accuses health agency of biodefence bias
}

\section{Erika Check, Washington}

Hundreds of US biologists have signed a letter protesting at what they see as the excessive use of bacteriology funds for the study of bioterror threats.

The letter, which reflects growing unease among researchers, was due to be delivered this week to managers at the National Institutes of Health (NIH), US lawmakers and the leaders of seven scientific societies.

"The diversion of research funds from projects of high public-health importance to projects of high biodefence relevance represents a misdirection of NIH priorities and a crisis for NIH-supported microbiological research," the letter states.

Its 750 signers include two Nobel laureates and seven past presidents of the American Society for Microbiology. The protest was organized by molecular biologist Richard Ebright of Rutgers University in Piscataway, New Jersey. In the letter, Ebright writes that the National Institute of Allergy and Infectious Diseases (NIAID) awarded 15 times more biodefence grants between the beginning of 2001 and the end of 2004 than it awarded during the previous fouryear period.

Meanwhile, Ebright says, the agency cut grants to study non-biodefence models, such as Escherichia coli, by $41 \%$ and grants to study non-biodefence microbes that cause disease by $27 \%$. He argues that this shift is preventing important advances in science and public health, and actually increases the risk of a bioterorrism incident.

"Bioweapons agents cause, on average, zero deaths per year in the United States, in contrast to a broad range of non-prioritized microbial pathogens that cause tens or hundreds of thousands of deaths per year," Ebright says.
Not just funders but investigators are shifting their focus to biodefence-related microbes, it seems. "We have become unbalanced," says Martha Howe of the University of Tennessee in Memphis, a past president of the American Society for Microbiology. Researchers are just not making the basicscience applications, she explains.

But Anthony Fauci, director of the NIAID, says he disagrees with the premise of the protest. "Although I have a great deal of respect for the people who signed that letter, if they understood all the issues and numbers involved I don't think they would be as concerned,"he says.

Fauci cites the NIAID's own data, which show that the agency funded about the same amount of research in basic bacteriology in 2000 as in 2004. Over that period, Fauci says, the number of grants increased slightly, from 131 to 137 , and never dropped below 120, while the funding dropped very slightly, from $\$ 40,741,867$ to $\$ 40,502,815$, after hitting a low of $\$ 34,168,719$ in 2003 . Fauci says his data are more appropriate than Ebright's, because they track all awards made across the institute.

"Ebright's saying that biodefence is taking away from non-biodefence infectious disease and microbiology," says Fauci, "and the facts clearly show that is not the case." He adds that grants awarded outside biodefence have dropped across the entire NIH owing to tight fiscal restraints in recent years. Just last week, Fauci said that the institute might also have to cut AIDS research.

But for Ebright, that is simply proof that biodefence spending is damaging other research. "The main constraint that is placing pressure on all other components is the biodefence budget," he says.
Pasteur researchers win fight to stay in city centre

Declan Butler, Paris

Scientists at the Pasteur Institute in Paris have won a long running battle over plans to move labs to a commercial zone on the outskirts of the city. In a report presented to the management on 24 February, external arbitrators said that the move was "not necessary".

The mediators were John Skehel, a virologist and director of Britain's National Institute for Medical Research in London, and John Wills, the UK institute's administrator. They said that the Pasteur's plans to renovate its labs in central Paris could be accomplished in phases, without moving staff elsewhere.

Philippe Kourilsky, the directorgeneral of the Pasteur Institute, had planned to move hundreds of scientists to a new site at Fresnes, southeast of Paris (see Nature 432, 788; 2004). Staff protested that the site was in an undesirable area with poor public transportation. A petition signed by more than half the staff says that they "understand neither the necessity, nor the rationale" of the move.

The report highlights staff concerns that there should be "minimum effect on the progress of interactive research programmes during refurbishment". Additional space could be created, it adds, by temporarily moving BioTop, Pasteur's biotechnology 'incubator unit', to one of Paris's many science parks.

"The mediators' conclusions are a complete disavowal of management," says Agnès Labigne, head of Pasteur's Pathogenesis of Mucosal Bacteria unit.

Stewart Cole, senior vice-president for scientific affairs, says management will take the report's advice. "Skehel and Wills did a serious job; they came here six times, and had complete freedom to go anywhere, and to speak to anyone," he says. "Their conclusions are clear."

Although scientists seem likely to stay on campus during the refurbishment, a broader question remains regarding the need to expand to a second or new campus - to build high-throughput biology platforms, for example. Cole says that this will be given "more thought".

The mediators' report emphasized that any expansion should be firmly based on a long-term scientific strategy worked out in full consultation with the institute's researchers. "What we need now is reconciliation," says Cole. "The report provides us with the framework to do this." 